\title{
Four SNPs of insulin-induced gene 1 associated with growth and carcass traits in Qinchuan cattle in China
}

\author{
Y. Liu, X.L. Liu, H. He and Y.L. Gu \\ Shaanxi Key Laboratory of Molecular Biology for Agriculture, \\ College of Animal Science and Technology, Northwest A \& F University, \\ Yangling, Shaanxi, P.R. China \\ Corresponding author: X.L. Liu \\ E-mail: liuxiaolin@nwsuaf.edu.cn
}

Genet. Mol. Res. 11 (2): 1209-1216 (2012)

Received September 19, 2011

Accepted January 23, 2012

Published May 8, 2012

DOI http://dx.doi.org/10.4238/2012.May.8.3

\begin{abstract}
The insulin-induced gene 1 (Insig-1) is a regulator of lipid metabolism and plays an important role in the sterol-mediated regulation of SREBP, SCAP and HMG-CoA reductase. We used PCRRFLP and DNA sequencing to detect polymorphisms of the Insig-1 gene in 215 individuals of the Qinchuan cattle breed. Four SNPs [4366(A>G), 4534( $\mathrm{T}>\mathrm{C}), \quad 5001(\mathrm{~T}>\mathrm{C})$, and 5235(G>A)] were indentified. The association of the genetic viariation with growth and carcass traits (body length, withers height, hip width, slaughter weight, and carcass weight) was analyzed. The individuals with better performance had the GG genotype at locus A4366G, and CC genotypes at locus T4534C and locus T5001C. These could be used for beef cattle breeding improvement in China. Additionally, linkage disequilibrium analysis reflected that all mutations were in low linkage disequilibrium with each other. We concluded that polymorphisms in the Insig-1 gene are associated with growth and carcass traits and could be used for marker-assisted selection and management in beef cattle breeding programs.
\end{abstract}

Key words: Insig-1; Qinchuan cattle; Association analysis; SNPs 


\section{INTRODUCTION}

Insulin-induced gene (Insig) is a regulator in lipid metabolism, which consists of two isoforms, Insig-1 and Insig-2, playing an important role in mediating sterol regulation through sterol regulatory element-binding protein (SREBP), SREBP cleavage-activating protein (SCAP) and 3-hydroxy-3-methylglutaryl-coenzyme A reductase (HMG-CoA reductase). The SREBP family is a crucial transcription factor in the synthesis of cholesterol, fatty acids, triacylglycerol, and glycerophospholipids (Hua et al., 1995; Horton et al., 2002). Insig proteins are shown to cooperate with sterols to inhibit exit of the SCAP/SREBP complex from the endoplasmic reticulum (ER) (Yabe et al., 2002, 2003). It can prevent the COP $\alpha$ proteins from binding to SCAP when SCAP binds to Insigs, and as a result, the SCAP/SREBP complex can no longer move to the Golgi (Sun et al., 2005, 2007). In another way, Insigs negatively regulate HMG-CoA reductase transcription by suppressing the activation of the ER membrane-bound transcription factor SREBP (Espenshade and Hughes, 2007). The human Insig-1 protein is composed of 277 amino acids, while the Insig-2 protein is composed of 225 amino acids (59\% identical). The main difference between the two proteins is that the Insig-2 lacks the N-terminal 50 amino acids of Insig-1. Both of them are highly conserved across species.

The Insig-1 gene is highly expressed in the liver. In animal cells, Insig-1 can cause the ER retention of the SCAP/SREBP complex and activate sterol-dependent HMG-CoA reductase degradation (Sever et al., 2003a,b).

In humans, the Insig-1 gene is located on chromosome 7 within band q36, and has been found to be $80 \%$ identical with the rat Insig-1 gene (Peng et al., 1997). In previous studies, Smith et al. (2010) reported that Insig-1 influences obesity-related hypertriglyceridemia in humans, and overexpression of Insig-1 has been shown to reduce high levels of TG in both liver and plasma of Zucker diabetic fatty rats (Takaishi et al., 2004). In addition, single knockout of Insig-1 in mice leads to increased total content of both cholesterol and TG in mouse liver (Engelking et al., 2005). These studies indicate that the differences in expression level or mutations of the Insig-1 gene may affect the composition of fat tissue in cattle. Based on these findings, we focused on the bovine Insig-1 gene, which could be a candidate gene of bovine body measurements and carcass traits.

The goal of our study was to identify the sequence variations in the Insig-1 gene in the Qinchuan beef cattle breed and the linkage disequilibrium (LD) between the variations and to analyze the relationship between sequence variations and growth/carcass traits.

\section{MATERIAL AND METHODS}

\section{Animal source and preparation of DNA samples}

Cattle from the Qinchuan commercial breeds were randomly selected, for a total of 215 animals. The animals ( $30 \pm 2$ months of age at slaughter) were reared in Shaanxi Province, P.R. China. The growth traits (withers height, body length and hip width) and carcass traits (slaughter weight, carcass weight and dressing percentage) were measured according to criteria of GB/T17238-1998 Cutting Standard of Fresh and Chilled Beef in China (China Standard Publishing House). All experimental protocols and animal care were performed according to authorization granted by the Chinese Ministry of Agriculture. Genomic DNA was isolated from $2 \%$ heparin-treated blood samples and stored at $-80^{\circ} \mathrm{C}$. 


\section{PCR-RFLP analysis}

Primers used to amplify Insig-1 were designed according to the published bovine Insig-1 sequence (GenBank accession No. NC_007302.4). The primer sequences, location and the fragment sizes are shown in Table 1.

\begin{tabular}{|c|c|c|c|c|}
\hline Amplified region & Primer & Primer sequence $\left(5^{\prime}-3^{\prime}\right)$ & Size (bp) & $\operatorname{Tm}\left({ }^{\circ} \mathrm{C}\right)$ \\
\hline Intron 2, exon 3 & $\begin{array}{l}\text { P1F } \\
\text { P1R }\end{array}$ & $\begin{array}{l}\text { GTGGGACTGTGGATGACT } \\
\text { GAGGAAGGCGATGGTGAT }\end{array}$ & 428 & 59.5 \\
\hline Intron 3 & $\begin{array}{l}\mathrm{P} 2 \mathrm{~F} \\
\mathrm{P} 2 \mathrm{R}\end{array}$ & $\begin{array}{l}\text { GCTGAGATGCCGTGTTGT } \\
\text { GGAGCGGATGTAGAGGAAGT }\end{array}$ & 500 & 61.5 \\
\hline
\end{tabular}

PCR amplifications were performed in a total of $15 \mu \mathrm{L}$, where the volume mixture contained: 50 ng genomic DNA as template, $10 \mathrm{mM}$ Tris- $\mathrm{HCl}$ buffer, $\mathrm{pH} 8.8$, containing 50 $\mathrm{mM} \mathrm{KCl}, 0.2 \mu \mathrm{M}$ of each primer, $200 \mu \mathrm{M}$ dNTP and $0.5 \mathrm{U}$ Taq DNA polymerase (MBI Fermentas, USA). The $\mathrm{Mg}^{2+}$ concentration was optimized for each primer set. PCR conditions were as follows: after an initial denaturation of $5 \mathrm{~min}$ at $95^{\circ} \mathrm{C}$, amplicons were generated for 35 cycles of $30 \mathrm{~s}$ at $94^{\circ} \mathrm{C}, 30 \mathrm{~s}$ at an optimal annealing temperature (Table 1), and $45 \mathrm{~s}$ at $72^{\circ} \mathrm{C}$, followed by a 10 -min final extension step at $72^{\circ} \mathrm{C}$.

Restriction fragment length polymorphism analysis was used to identify the genotypes of sequence variants. The PCR products were digested in a total volume of $10 \mu \mathrm{L}$ containing: 5 $\mu \mathrm{L}$ PCR product, $4 \mathrm{U}$ restriction enzyme $(0.4 \mu \mathrm{L}), 2 \mu \mathrm{L}$ reaction buffer and $2.6 \mu \mathrm{L} \mathrm{ddH}_{2} \mathrm{O}$. The mixture was incubated for $10 \mathrm{~h}$ at $37^{\circ} \mathrm{C}\left(\mathrm{Taq} \mathrm{I}\right.$ restriction enzyme digestion at $\left.65^{\circ} \mathrm{C}\right)$. Digested PCR products were mixed with $10 \mathrm{X}$ loading buffer and subjected to $3 \%$ agarose gel electrophoresis in $1 \mathrm{X}$ TBE at a constant voltage $(100 \mathrm{~V})$ for $1.5 \mathrm{~h}$ at room temperature. Individuals were then genotyped based on different electrophoresis patterns. Fragments displaying different PCR-RFLP patterns were purified with Qiaquick spin columns (Qiagen) and sequenced with the ABI 3730 sequencer (ABI, Foster City, CA, USA).

\section{Linkage disequilibrium and statistical analysis}

The pattern of pairwise LD between the SNPs was measured by LD coefficient (D') and correlation coefficient $\left(\mathrm{r}^{2}\right)$, and visualization of $\mathrm{LD}$, and measurements were determined using the Haploview program (http://www.broad.mit.edu/mpg/haploview).

Allelic frequencies were determined by direct counting from observed genotypes. The $\chi^{2}$ test was used to determine Hardy-Weinberg equilibrium of the mutation. Population genetic indices, including heterozygosity $\left(H_{\mathrm{E}}\right)$, homozygosity $\left(H_{\mathrm{O}}\right)$, polymorphism information content (PIC), and effective allele numbers $\left(N_{\mathrm{E}}\right)$ were calculated according to Nei and Roychoudhury (1974).

The SPSS software (Version 16.0) was used to analyze the association between genotypes and traits in Qinchuan cattle, using the following linear model: Yijkl $=\mu+\mathrm{Bfi}+\mathrm{Mj}+\mathrm{Gk}$ + eijkl, where: Yijkl $=$ traits observed; $\mu=$ overall population mean; $\mathrm{Bfi}=$ fixed effect of the ith breed and farm; $\mathrm{Mj}$ = fixed effect of the $\mathrm{jth}$ of slaughter; $\mathrm{Gk}=$ fixed effect of the kth single SNP marker genotype, and eijkl = random error. 


\section{RESULTS}

In this study, four SNPs were detected. Sequencing analysis of the mutation revealed that the mutations occurring at positions $4366(A>G), 4534(T>C), 5001(T>C)$, and 5235(G $>A)$ of the cattle Insig-1 gene. The A4366G and T4534C mutations were in introns 2, while the T5001C and G5235A mutations were in introns 3 according to the cattle Insig-1 (GenBank accession No. NC_007302.4). PCR-RFLP was used to genotype the individuals. According to the sequence variants, the PCR product could be digested with $T a q \mathrm{I}, A f a \mathrm{I}, H h a \mathrm{I}$, and MspI restriction enzymes. At locus A4366G, three possible genotypes were defined by three distinct banding patterns: AA (a fragment of 428 bp), AG (428, 318 and $110 \mathrm{bp}$ ) and GG (318 and $110 \mathrm{bp}$ ). At locus $\mathrm{T} 4534 \mathrm{C}$, three possible genotypes were defined by three distinct banding patterns: CC (a fragment of $428 \mathrm{bp}$ ), TC (428, 278 and $150 \mathrm{bp}$ ) and TT (278 and $150 \mathrm{bp}$ ). At locus T5001C, three possible genotypes were defined by three distinct banding patterns: TT (a fragment of $500 \mathrm{bp})$, TC (500, 298 and 202 bp) and CC (298 and 202 bp). At locus G5235A, three possible genotypes were defined by three distinct banding patterns: AA (a fragment of $500 \mathrm{bp}), \mathrm{AG}(500,439$ and $61 \mathrm{bp})$ and GG (439 and $61 \mathrm{bp})$.

The means and standard deviations (SD) for traits analyzed in this study are shown in Table 2. The allelic and genotypic frequencies, genetic diversity parameters $\left(H_{\mathrm{O}}, H_{\mathrm{E}}, N_{\mathrm{E}}\right.$, and PIC) of the four SNPs are shown in Table 3. According to Table 3, the four loci of Qinchuan cattle were in Hardy-Weinberg equilibrium $(\mathrm{P}>0.05)$. It showed that the Qinchuan cattle breed was in a dynamic equilibrium in artificial selection, migration and genetic drift function. The PIC ranged from 0.3653 to 0.3716 , which reflected an intermediate genetic diversity of the Qinchuan bovine Insig-1 gene in the population analyzed.

\begin{tabular}{lrr} 
Table 2. Means and standard deviations (SD) for traits. & & \\
\hline Traits & Mean & SD \\
\hline Body height $(\mathrm{cm})$ & 140.22 & 4.26 \\
Body length $(\mathrm{cm})$ & 150.71 & 6.14 \\
Hip width $(\mathrm{cm})$ & 48.00 & 3.66 \\
Slaughter weight $(\mathrm{kg})$ & 497.96 & 63.67 \\
Carcass weight $(\mathrm{kg})$ & 268.87 & 36.99 \\
\hline
\end{tabular}

\begin{tabular}{|c|c|c|c|c|c|c|c|c|}
\hline Mutation & Genotype & Frequencies & Allele frequencies & $\chi^{2}$ & $H_{\mathrm{O}}$ & $H_{\mathrm{E}}$ & $N_{\mathrm{E}}$ & PIC \\
\hline \multirow[t]{3}{*}{ A4366G } & $\mathrm{AA}(\mathrm{N}=29)$ & 0.1733 & $\mathrm{~A}(0.4163)$ & $5.3706^{*}$ & 0.5140 & 0.4860 & 1.9455 & 0.3679 \\
\hline & $\mathrm{AG}(\mathrm{N}=121)$ & 0.4860 & $\mathrm{G}(0.5837)$ & & & & & \\
\hline & $\mathrm{GG}(\mathrm{N}=65)$ & 0.3407 & & & & & & \\
\hline \multirow[t]{3}{*}{$\mathrm{T} 4534 \mathrm{C}$} & $\mathrm{TT}(\mathrm{N}=28)$ & 0.1619 & $\mathrm{~T}(0.4023)$ & $3.7209 *$ & 0.5191 & 0.4819 & 1.9265 & 0.3653 \\
\hline & $\mathrm{TC}(\mathrm{N}=117)$ & 0.4809 & $\mathrm{C}(0.5977)$ & & & & & \\
\hline & $\mathrm{CC}(\mathrm{N}=70)$ & 0.3572 & & & & & & \\
\hline \multirow[t]{3}{*}{ T5001C } & $\mathrm{TT}(\mathrm{N}=76)$ & 0.3535 & $\mathrm{~T}(0.6163)$ & $2.7847 *$ & 0.5270 & 0.4730 & 1.8974 & 0.3716 \\
\hline & $\mathrm{TC}(\mathrm{N}=113)$ & 0.5256 & $\mathrm{C}(0.3837)$ & & & & & \\
\hline & $\mathrm{CC}(\mathrm{N}=26)$ & 0.1209 & & & & & & \\
\hline \multirow[t]{3}{*}{ G5235A } & $\mathrm{GG}(\mathrm{N}=26)$ & 0.1209 & $\mathrm{~A}(0.6023)$ & $4.6141 *$ & 0.5209 & 0.4791 & 1.9196 & 0.3671 \\
\hline & $\mathrm{AG}(\mathrm{N}=119)$ & 0.5535 & $\mathrm{G}(0.3977)$ & & & & & \\
\hline & $\mathrm{AA}(\mathrm{N}=70)$ & 0.3256 & & & & & & \\
\hline
\end{tabular}

$H_{\mathrm{O}}=$ observed homozygosity; $H_{\mathrm{E}}=$ expected heterozygosity; $N_{\mathrm{E}}=$ effective allele numbers; $\mathrm{PIC}=$ polymorphism information content. 
Haplotypes generally had more information content than single SNP. Therefore, we performed LD and haplotype analysis for the four SNPs in Qinchuan cattle breed. The LD structure as measured by $\mathrm{D}^{\prime}$ and $\mathrm{r}^{2}$ was calculated, and these data are presented in Table 4. According to the data, the $\mathrm{D}^{\prime}$ value ranged from 0.076 to 0.419 , and $\mathrm{r}^{2}$ was from 0.006 to 0.1 . This showed that all mutations were in low LD with each other.

Table 4. Estimated values of $L D$ analysis between 4 mutation sites within Insig- 1.
\begin{tabular}{lcccc}
\hline SNP & 1 & 2 & 3 & 4 \\
\hline 1 & & $\mathrm{D}^{\prime}=0.106$ & $\mathrm{D}^{\prime}=0.192$ & $\mathrm{D}^{\prime}=0.196$ \\
2 & $\mathrm{r}^{2}=0.006$ & $\mathrm{D}^{\prime}=0.076$ & $\mathrm{D}^{\prime}=0.158$ \\
3 & $\mathrm{r}^{2}=0.006$ & $\mathrm{D}^{\prime}=0.419$ \\
4 & $\mathrm{r}^{2}=0.006$ & $\mathrm{r}^{2}=0.013$ & \\
\hline
\end{tabular}

$\mathrm{D}^{\prime}$ and $\mathrm{r}^{2}$ above and below the diagonal, respectively. $1=\mathrm{A} 4366 \mathrm{G}, 2=\mathrm{T} 4534 \mathrm{C}, 3=\mathrm{T} 5001 \mathrm{C}, 4=\mathrm{A} 5235 \mathrm{G}$.

The association of the four mutations in Insig-1 with growth and carcass traits (body length, withers height, hip width, slaughter weight, and carcass weight) in Qinchuan cattle was analyzed, and the results are shown in Table 5. According to Table 5, at locus A4366G, the animals with the GG genotype had wider hip width and heavier carcass weight than those with the AA genotype $(\mathrm{P}<0.05)$, and the animals with the GG genotype had extremely heavier slaughter weight compared to the AA genotype $(\mathrm{P}<0.01)$. At locus $\mathrm{T} 4534 \mathrm{C}$, the $\mathrm{CC}$ genotype was better than TC and TT genotypes, the animals with the CC genotype had greater body length and hip width than those with the TT genotype $(\mathrm{P}<0.05)$, the animals with the TC genotype had greater hip width than those with the TT genotype $(\mathrm{P}<0.05)$, and $\mathrm{CC}$ and TC genotypes had extremely greater withers height than those with the TT genotype $(\mathrm{P}<0.01)$. At locus T5001C, the animals with the CC genotype had longer body length than those with the TT genotype $(\mathrm{P}<0.05)$. There were no significant differences within genotypes at locus G5235A, but the animals with the AA genotype tended to have better traits than those with AG and GG genotypes with regard to growth and carcass traits.

Table 5. Association of SNPs with growth and carcass traits.
\begin{tabular}{lcrccccc}
\hline Locus & Genotype & N & Body length $(\mathrm{cm})$ & Withers height $(\mathrm{cm})$ & Hip width $(\mathrm{cm})$ & Slaughter weight $(\mathrm{kg})$ & Carcass weight $(\mathrm{kg})$ \\
\hline A4366G & AA & 29 & $139.00 \pm 1.231$ & $148.471 \pm 1.485$ & $47.100 \pm 0.539^{\mathrm{b}}$ & $463.882 \pm 15.105^{\mathrm{B}}$ & $253.824 \pm 8.835^{\mathrm{b}}$ \\
& AG & 121 & $140.437 \pm 0.603$ & $150.887 \pm 0.727$ & $47.647 \pm 0.876^{\mathrm{ab}}$ & $496.254 \pm 7.391^{\mathrm{AB}}$ & $266.592 \pm 4.323^{\mathrm{ab}}$ \\
& GG & 65 & $140.333 \pm 0.757$ & $151.267 \pm 0.913$ & $48.655 \pm 0.429^{\mathrm{a}}$ & $513.533 \pm 9.284^{\mathrm{A}}$ & $278.142 \pm 5.430^{\mathrm{a}}$ \\
& P & & 0.569 & 0.262 & 0.075 & 0.021 & 0.051 \\
T4534C & CC & 28 & $140.953 \pm 0.766^{\mathrm{a}}$ & $151.674 \pm 0.906^{\mathrm{A}}$ & $49.140 \pm 0.547^{\mathrm{a}}$ & $502.233 \pm 9.201$ & $271.451 \pm 5.405$ \\
& TC & 117 & $140.324 \pm 0.596^{\mathrm{ab}}$ & $151.225 \pm 0.705^{\mathrm{A}}$ & $47.507 \pm 0.425^{\mathrm{b}}$ & $501.676 \pm 7.549$ & $269.508 \pm 4.253$ \\
& TT & 70 & $138.158 \pm 1.152^{\mathrm{b}}$ & $146.579 \pm 1.364^{\mathrm{B}}$ & $47.158 \pm 0.823^{\mathrm{b}}$ & $480.316 \pm 14.594$ & $255.32 \pm 8.221$ \\
& P & & 0.129 & 0.005 & 0.038 & 0.394 & 0.238 \\
T5001C & CC & 76 & $141.303 \pm 0.880$ & $152.667 \pm 1.055^{\mathrm{a}}$ & $48.833 \pm 0.636$ & $505.242 \pm 11.118$ & $274.030 \pm 6.446$ \\
& TC & 113 & $140.056 \pm 0.688$ & $150.611 \pm 0.824^{\mathrm{ab}}$ & $47.620 \pm 0.497$ & $500.278 \pm 8.691$ & $270.322 \pm 5.039$ \\
& TT & 26 & $139.630 \pm 0.746$ & $150.284 \pm 0.864^{\mathrm{b}}$ & $47.848 \pm 0.538$ & $492.457 \pm 9.417$ & $263.457 \pm 5.460$ \\
G5235A & P & & 0.337 & 0.066 & 0.307 & 0.665 & 0.428 \\
& GG & 26 & $140 \pm 0.751$ & $150.413 \pm 0.906$ & $47.859 \pm 0.539$ & $489.217 \pm 9.387$ & $263.848 \pm 5.449$ \\
& AG & 119 & $140.25 \pm 0.618$ & $150.426 \pm 0.745$ & $48.257 \pm 0.443$ & $499.574 \pm 7.720$ & $269.491 \pm 4.482$ \\
& AA & 70 & $140.632 \pm 1.169$ & $152.421 \pm 1.410$ & $47.263 \pm 0.838$ & $513.368 \pm 14.606$ & $278.789 \pm 8.478$ \\
& P & & 0.897 & 0.425 & 0.557 & 0.366 & 0.33 \\
\hline
\end{tabular}

Data are reported as means \pm SE. Values with different superscript letters within the same row differ significantly at $\mathrm{P}<0.01(\mathrm{~A}, \mathrm{~B})$ and $\mathrm{P}<0.05(\mathrm{a}, \mathrm{b})$. 


\section{DISCUSSION}

Previous research on Insig-1 has largely focused on human obesity and type 2 diabetes. Experiments with siRNA suggest that Insig-1 is related to SREBP1c mediated regulation of phosphoenolpyruvate carboxykinase (PCK2) (Krapivner et al., 2007). Recent research suggests that variation in Insig-1 is unlikely to have a major effect on type 2 diabetes (Szopa et al., 2010). Han et al. (2010) found that mRNA abundance and expression of INSIG isoforms are affected by the stage of lactation in the mouse. Another study found that Insig-2 is associated with weight gain, obesity and hypercholesterolemia. Variation in Insig-2 is associated with obesity in adults and children (Herbert et al., 2006). Another study indicates that polymorphism of Insig-2 is associated with antipsychotic-induced weight gain (Tiwari et al., 2010). Until now, there have been no studies about genetic variation relevant to the bovine Insig-1 gene. We choose it as a candidate gene to identify its sequence variation and the association between the polymorphism and growth and carcass traits in the Qinchuan cattle population in order to study the function of the Insig-1 gene in this cattle breed.

In this study, the associations between the mutation at locus A4366G and the growth and carcass traits showed that genotype had a significant effect on hip width, slaughter weight and carcass weight. The genotypes at locus T4534C had a significant effect on body length, wither height and hip width. The genotypes at locus T5001C had a significant effect on hip width. In addition, there were no significant differences between genotypes at locus G5235A. Based on these results, the individuals with better performance with the GG genotype at locus A4366G and CC genotypes at locus T4534C and locus T5001C could be used for the development of new breeds of beef cattle in China, and the first three loci could be used as remarkable molecular markers for better performance in the bovine industry.

Selection during domestication and improvement could influence the LD level of a gene (Toomajian et al., 2002; Saunders et al., 2002, 2005). In this study, all mutations were in low LD with each other. This suggests that the Qinchuan cattle still need a long time selection for better performance, which could increase the LD. Because of the weak linkage within the SNPs, we did not do an analysis of haplotype structure, haplotype frequencies and combined haplotypes.

According to previous studies, mutations in intron regions may affect the level of gene expression, so as to change the phenotypic traits of the animal. Mutations in the intron region of the IGF2 gene are closely related to muscle and fat deposit (Knoll et al., 2000; Liu et al., 2003). Liu et al. (2010) found a C to T variation in intron 14 of the bovine ATP1A1 gene, and they also found significant correlations between the ATP1A1 gene polymorphism and the coefficient of heat tolerance. In this study, we found that all four SNPs in the bovine Insig-1 gene exist in the intron region, which may affect the economic traits by affecting the translation efficiency of Insig-1 itself. To clarify the mechanism of the effect, transcriptional analysis for the SNPs occurring in the intron region would be required.

This study is the first to report four novel SNPs in the bovine Insig-1 gene, and we analyzed their association with growth and carcass traits in Qinchuan cattle. The results showed that genotype had a significant effect on the growth and carcass traits. The individuals with better performance could be used for beef cattle breeding in China. Polymorphism in the intron regions may affect expression. Further research is needed to clarify the role of the genetic variants of the Insig-1 gene and to determine the mRNA expression levels of the Insig-1 gene. 
In conclusion, this study indicates that the Insig- 1 gene has potential effects on growth and carcass traits, opening up possibilities for cattle breeding and improvement in gene-assisted selection.

\section{ACKNOWLEDGMENTS}

Research supported by the 12th "Five-Year" National Science and Technology Key Project (\#2011AA100307), the National "863" Program of China (\#2008AA101010), and the “13115” Sci-Tech Innovation Program of Shaanxi Province (\#2008ZDKG-11).

\section{REFERENCES}

Engelking LJ, Liang G, Hammer RE, Takaishi K, et al. (2005). Schoenheimer effect explained--feedback regulation of cholesterol synthesis in mice mediated by Insig proteins. J. Clin. Invest. 115: 2489-2498.

Espenshade PJ and Hughes AL (2007). Regulation of sterol synthesis in eukaryotes. Annu. Rev. Genet. 41: 401-427.

Han LQ, Li HJ, Wang YY, Zhu HS, et al. (2010). mRNA abundance and expression of SLC27A, ACC, SCD, FADS, LPIN, INSIG, and PPARGC1 gene isoforms in mouse mammary glands during the lactation cycle. Genet. Mol. Res. 9: 1250-1257.

Herbert A, Gerry NP, McQueen MB, Heid IM, et al. (2006). A common genetic variant is associated with adult and childhood obesity. Science 312: 279-283.

Horton JD (2002). Sterol regulatory element-binding proteins: transcriptional activators of lipid synthesis. Biochem. Soc. Trans. 30: 1091-1095.

Hua X, Wu J, Goldstein JL, Brown MS, et al. (1995). Structure of the human gene encoding sterol regulatory element binding protein-1 (SREBF1) and localization of SREBF1 and SREBF2 to chromosomes 17p11.2 and 22q13. Genomics 25: 667-673.

Knoll A, Putnova L, Dvorak J and Cepica S (2000). A NciI PCR-RFLP within intron 2 of the porcine insulin-like growth factor 2 (IGF2) gene. Anim. Genet. 31: 150-151.

Krapivner S, Chernogubova E, Ericsson M, Ahlbeck-Glader C, et al. (2007). Human evidence for the involvement of insulin-induced gene 1 in the regulation of plasma glucose concentration. Diabetologia 50: 94-102.

Liu GL, Jiang SW, Xiong YZ, Zheng R, et al. (2003). Association of PCR-RFLP polymorphisms of IGF2 gene with fat deposit related traits in pig resource family. Yi Chuan Xue Bao 30: 1107-1112.

Liu YX, Zhou X, Li DQ, Cui QW, et al. (2010). Association of ATP1A1 gene polymorphism with heat tolerance traits in dairy cattle. Genet. Mol. Res. 9: 891-896.

Nei M and Roychoudhury AK (1974). Sampling variances of heterozygosity and genetic distance. Genetics 76: 379-390.

Peng Y, Schwarz EJ, Lazar MA, Genin A, et al. (1997). Cloning, human chromosomal assignment, and adipose and hepatic expression of the CL-6/INSIG1 gene. Genomics 43: 278-284.

Saunders MA, Hammer MF and Nachman MW (2002). Nucleotide variability at G6pd and the signature of malarial selection in humans. Genetics 162: 1849-1861.

Saunders MA, Slatkin M, Garner C, Hammer MF, et al. (2005). The extent of linkage disequilibrium caused by selection on G6PD in humans. Genetics 171: 1219-1229.

Sever N, Song BL, Yabe D, Goldstein JL, et al. (2003a). Insig-dependent ubiquitination and degradation of mammalian 3-hydroxy-3-methylglutaryl-CoA reductase stimulated by sterols and geranylgeraniol. J. Biol. Chem. 278: 5247952490.

Sever N, Yang T, Brown MS, Goldstein JL, et al. (2003b). Accelerated degradation of HMG CoA reductase mediated by binding of insig-1 to its sterol-sensing domain. Mol. Cell 11: 25-33.

Smith EM, Zhang Y, Baye TM, Gawrieh S, et al. (2010). INSIG1 influences obesity-related hypertriglyceridemia in humans. J. Lipid. Res. 51: 701-708.

Sun LP, Li L, Goldstein JL and Brown MS (2005). Insig required for sterol-mediated inhibition of Scap/SREBP binding to COPII proteins in vitro. J. Biol. Chem. 280: 26483-26490.

Sun LP, Seemann J, Goldstein JL and Brown MS (2007). Sterol-regulated transport of SREBPs from endoplasmic reticulum to Golgi: Insig renders sorting signal in Scap inaccessible to COPII proteins. Proc. Natl. Acad. Sci. U. S. A. 104: 6519-6526.

Szopa M, Meirhaeghe A, Luan J, Moreno LA, et al. (2010). No association between polymorphisms in the INSIG1 gene 
and the risk of type 2 diabetes and related traits. Am. J. Clin. Nutr. 92: 252-257.

Takaishi K, Duplomb L, Wang MY, Li J, et al. (2004). Hepatic insig-1 or -2 overexpression reduces lipogenesis in obese Zucker diabetic fatty rats and in fasted/refed normal rats. Proc. Natl. Acad. Sci. U. S. A. 101: 7106-7111.

Tiwari AK, Zai CC, Meltzer HY, Lieberman JA, et al. (2010). Association study of polymorphisms in insulin induced gene 2 (INSIG2) with antipsychotic-induced weight gain in European and African-American schizophrenia patients. Hum. Psychopharmacol. 25: 253-259.

Toomajian C and Kreitman M (2002). Sequence variation and haplotype structure at the human HFE locus. Genetics 161: 1609-1623.

Yabe D, Brown MS and Goldstein JL (2002). Insig-2, a second endoplasmic reticulum protein that binds SCAP and blocks export of sterol regulatory element-binding proteins. Proc. Natl. Acad. Sci. U. S. A. 99: 12753-12758.

Yabe D, Komuro R, Liang G, Goldstein JL, et al. (2003). Liver-specific mRNA for Insig-2 down-regulated by insulin: implications for fatty acid synthesis. Proc. Natl. Acad. Sci. U. S. A. 100: 3155-3160. 